\title{
Effects of Mobile Learning Science Course on Students' Academic Achievement and Their Opinions about the Course
}

\author{
Mirac Furkan Bayar ${ }^{1}$, Uluhan Kurt ${ }^{2 *}$ \\ ${ }^{1}$ Erzurum Provincial Directorate of National Education, Erzurum, Turkey, ${ }^{2}$ Erzurum Provincial Directorate of National Education, Erzurum,Turkey \\ *Corresponding author: uluhaaan@hotmail.com
}

\section{ABSTRACT}

The aim of this research was to investigate the effect of mobile learning on students' academic achievements and their opinions about the course. This research was a mixed study where both quantitative and qualitative methods were used together. The quantitative part of the study used quasi-experimental models in a pre-test/post-test design according to the patterned paired control group. In the qualitative part, a semi-structured interview method was used from descriptive models. The study group consisted of 28 students studying in the $8^{\text {th }}$ grade of a state secondary school in the Pasinler district of Erzurum Province of Turkey in the 2018-2019 academic years. The study lasted approximately 6 weeks. As a result of the study, it was observed that there was a positive increase in academic achievement in favor of the experimental group of students. Moreover, although there were differences of opinion among the students, a large majority declared that the mobile supported learning increased their interest towards the course. Recommendations are made based on this research.

KEY WORDS: Academic achievement; mobile learning, structure and properties of matter; opinion toward the course

\section{INTRODUCTION}

T he rapid development of technology has also affected education and training environments and gradually started to leave the traditional education place toward e-learning (Kılıç, 2015). While the concept of hosting information has lost its importance, the ability to access information has gained importance. To reach information, technological tools should be used at a high level. Multimedia designs should be developed using educationally even computers, tablets and even smartphones (Balay, 2004). These multimedia environments are combined under the e-learning framework. E-Learning covers all technology-based learning and teaching activities. Mobile learning can be accepted as a sub-dimension of e-learning (Semerci et al., 2004). In particular, the use of mobile devices which have increased in an extraordinary manner should be studied in terms of education.

Mobile learning can be thought of as supporting learning environments through technological tools such as computers, tablets, or smartphones (Sharples et al., 2010). One of the most important features of mobile devices is to support and develop learning environments without space or time limits (Traxler, 2007). According to Trifonova and Ronchetti (2004), the students have explained to them the process of undertaking a teaching activity by means of a mobile tool. Learning does not only occur between the four walls but is always an ongoing process (Yokuş, 2016). For this reason, the necessary infrastructure and plans, which also contain mobile applications, should be prepared and the e-learning environments should be brought into the education system (Köseoğlu and Tümay, 2013).

Thanks to the ability to be online, mobile tools provide interactive environments and enable various activities. Students can interact with each other or with teachers. With the help of mobile tools, it is thought that the development of chat environments will support not only direct learning but also indirect learning (Keskin and Kilınç, 2015). Because learning is both a conscious and unconscious process. As a matter of fact, the basis of the Turkish National Education system has two sections: Non-formal education and formal education. Mobile supported applications can be supported in both parts (Öztürk and Talas, 2015).

With these tools, it is thought that all people will take part in gaining the social skills they need. Individuals will be able to recognize the rules of society and their social role (Bandura and Walters, 1977). With the support of out-of-school activities, students hungry for knowledge and feelings of curiosity can be supported. Students' interests and attitudes towards the course may also be changed positively (Ertaş et al., 2011). Mobile tools can be used actively in learning environments by developing the necessary software (Motiwalla, 2007). It should enable students to be in individual activities or to progress at own speed. The e-learning environment has been noted to be the link between today and the future so it should be supported and developed (Rosenberg, 2001).

Mobile learning can be used to explore existing educational needs. In addition, individuals' interest in mobile tools can 
be used in the use of positive classroom environments and in supporting meaningful learning (Chinnery, 2006). Especially with the use of these tools, individuals will be able to adapt to new devices more easily. To use mobile devices effectively, schools should be equipped with technological tools and necessary infrastructure should be prepared (Aksoy, 2003). Therefore, the number and quality of educational software and e-content should be increased (Caudill, 2007).

One of the most important features of mobile learning is that it allows for distance education (İşman, 2008). The three basic elements of distance education are teacher, student, and communication. In this context, mobile tools that support lifelong learning improve communication and provide better learning environments (Elçiçek and Bahçeci, 2017). For this reason, mobile learning environments contribute to the further development of distance education applications that have been spreading recently. Fig. 1 presents the basic principles of mobile learning:

A major step was taken with the Fatih Project for the development of e-learning environments in our country. Tablet computers were distributed to students who were equipped with their school smart boards and they were provided with the necessary substructures (Ekici and Y1lmaz, 2013; Kamac1 and Durukan, 2012). Educational e-content was made available to stakeholders through the training information network (EBA).

Educational e-contents are student-centered and allow social interaction. In addition, the education information network (EIN) offers students the opportunity to learn individually (MoNE, 2015). It is a cognitive and social network prepared in a way to appeal to students (MoNE, 2015). However, videos on EIN are not used effectively and are not being developed sufficiently (Bayar et al., 2018). For the more active use of EIN, which is also a mobile application, it is recommended that the mobile supported learning approach be employed (Kapidere and Çetinkaya, 2017).

When the literature is examined, it has been determined that mobile learning has a positive effect on students' academic achievement. It has been noted that mobile supported learning environments increased students' academic achievement (Atıc1, 2010; Elçiçek and Bahçeci, 2017). Gürkan (2017) stated that mobile supported environments showed positive

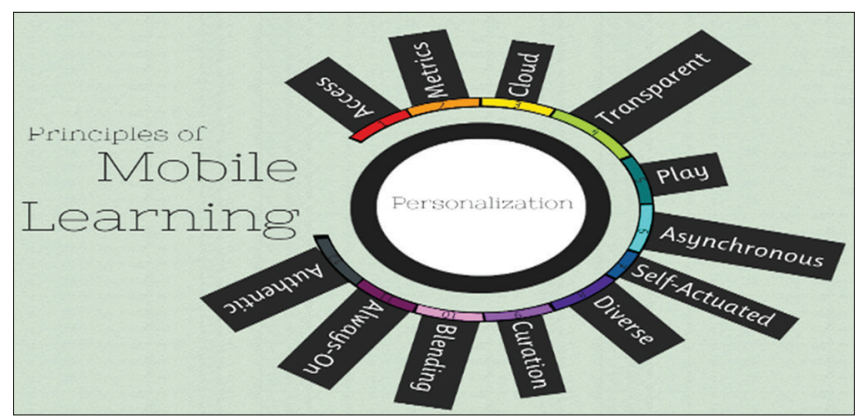

Figure 1: Basic principles of mobile learning (Centre of Language Education, 2018) development of students' attitudes. Şenel (2016) stated in his research on mobile driving habits that the self-efficacy beliefs of the students differ significantly according to the variables such as the monthly income of the family, gender, having mobile internet package, and class levels. Mahat et al. (2012) reported that the level of self-efficacy of mobile learning was moderate, while the level of individual innovation from mobile learning environments was high as was the readiness for mobile learning. Ruchter et al. (2010) investigated the effect of using mobile tools in environmental literacy and stated that there was a positive development in the motivation of the participants. Yıldırım (2012) designed an educational game to increase the learning activities of mobile environments in foreign languages and explained that the development of students' academic achievements at the end of the process. Yang (2012) explored the impact of mobile devices on language learning in university students. As a result of that study, it was stated that students' attitudes toward language learning developed and their motivations increased. Küle (2012) conducted a survey to investigate the perceptions of graduate students towards mobile learning and explained that their perceptions of mobile learning were high. Tanriverdi (2011) questioned students' views at the end of the process that designed distance learning environments with mobile learning. He reported that mobile learning environments were effective in giving immediate feedback by the teacher, making changes in homework, and being aware of learning environments. Lan and Hsieh (2009) stated that the mobile tools that students used to strengthen communication between the teacher and the student improved their relationship with the teacher positively. In addition, students stated that there was an increase in their questioning skills and motivation. Rau et al. (2008) stated that mobile tools improved communication in the learning environment and increased student motivation. Finally, Mcconatha et al. (2008) reported that mobile learning environments had a positive effect on students' repetition, practicality behavior, and their academic achievement increased.

This study was designed to investigate the students' academic achievement and to examine the student' perspective on mobile learning environments. In this context, this study intends to support further improvements in mobile learning. Therefore, it is thought that this research will raise awareness among stakeholders about mobile learning environments, guide teachers, and contribute to the development of e-learning environments.

As the main purposes of this research were to investigate the effect of mobile learning on the students' academic achievements and their opinions about the course, the following questions were investigated:

1. What is the effect of mobile learning on the academic achievement of the eighth-grade students' matters and properties unit?

2. What are students' views on mobile learning? 


\section{MATERIALS AND METHODS}

\section{Research Design}

In this study, a mixed research method was used. This study used a combination of quantitative and qualitative patterns (Morse, 2016). In this way, the method was diversified. Method diversity is defined as the use of more than one research method and technique to answer the same research question (Yıldırım and Şimşek, 2011). For this reason, the use of a combination of qualitative and quantitative research methods is described as a method variation (Türnüklü, 2001). The use of quantitative and qualitative data supporting each other increases the validity and reliability of the research. In parallel, Creswell (2014) states that the combined use of different methods are important in determining the accuracy and validity of the collected data and explanations based on this data. In the quantitative dimension of the research, to investigate the effectiveness of mobile learning, "The Structure and Properties of the Matter Academic Achievement Test" (SPMAAT) developed by the researcher was applied as a pre-test and post-test. In the qualitative dimension, the students were asked to express their ideas in written form in accordance with the semi-structured interview form.

\section{Participants}

The population of the study was composed of $8^{\text {th }}$ grade students in the middle school in Erzurum in 2018-2019 academic years. The sample of the study consisted of 28 middle school $8^{\text {th }}$ grade students attending a state secondary school in Erzurum. In the sample, there were two groups: A control group $(n=15)$ and an experimental group $(n=13)$. The control group consisted of eight male students with seven female students; the experimental group consisted of eight female students and five male students. The sample was generated by appropriate sampling method. Proper sampling is a method that allows the researcher to easily recruit (Berg, 2001). Sampling can be used to select participants because of the limitations in money, time, or labor force (Creswell and Creswell, 2017).

\section{Data Collection Tools}

Both groups were offered "SPMAAT" as a pre-test and posttest. In addition, semi-structured interviews were conducted with experimental group students.

\section{The SPMAAT}

The SPMAAT was used to determine the academic achievement of the students in the "Structure and Properties of Matter" unit. For the SPMAAT, national scholarship exam questions were examined to develop the SMAAT. For the validity of the test, the renewed "Science Teaching Program" was examined, and the achievements were placed on the content table. Bloom's taxonomy was applied to the question pool, so as to ensure the inclusion of metacognitive areas. A multiple choice 29 item draft form was created. Later, these questions were evaluated by field experts. Five questions were removed as they were not directly related to course outcomes, and a pilot study was conducted. The pre-application of the test was carried out with the participation of 87 students. The analysis of item severity indices and item difficulty indices were performed. To ensure validity, high diversity index items were selected. The resulting analysis has been developed because of a multiple-choice 15 -item test. Every item has a correct answer. The reliability coefficient of the test Kuder-Richardson 20 was calculated as 0.79 . Correct answers are " 1 ", false or blank answers are " $0 . "$ The highest score that can be obtained from the test is 15 .

\section{Interview form}

A semi-structured interview form was developed by the researcher to receive feedback from students about mobileassisted learning. Questions in the interview form were along the lines of:

1. What are your thoughts on mobile learning?

2. Do you think your interest in the lesson has increased with mobile learning?

3. Do you think that your academic achievement has increased with mobile learning?

4. Can you tell us about the positive aspects of mobile learning?

5. Can you tell us about the negative aspects of mobile learning?

Students are also asked to respond in writing to the questions in the interview form.

\section{Application}

Experimental study was initiated by taking preliminary measurements (SPMAAT). These experimental procedures were applied in accordance with the daily plans and the application was completed by taking the last measurements (SPMAAT, semi-structured interview). Daily plans and necessary materials were prepared before starting the experimental procedures. Voluntary participation of the students was received. Teacher orientation activities were carried out for the 4-week applied research and necessary information about mobile learning was given. Throughout the research, ideas were exchanged, and communication was made.

There was no specific reason for the selection of the Structure and Properties of Matter Unit. This unit was chosen because it corresponds to the course flow. Lesson plans were prepared and presented to the specialist and experienced six science teachers. In addition, peer review was done and the final shape of the form. For extracurricular applications, a group interview platform was created with the help of a software. Teachers and students shared on this platform outside of the lesson. In addition, homework was given and followed on this platform. E-contents related to the course were shared. The teacher followed this platform and gave instant feedback not to cause false learning. The students have followed the tutorial by downloading the Educational Information Network mobile application. Videos about the course are followed.

In the control group, lessons were conducted according to curriculum-oriented science teaching. A science coursebook was used as the main course material. Techniques such as 
narration, question-answer, discussion, and brainstorming were used under the guidance of the teacher. The teacher introduced the basic concepts of the unit to the students. Students in the control group carried out activities such as reading, writing, speaking, and listening without mobile devices. The use of the smart board in the classroom continued throughout the application. The application lasted for 6 weeks and the same teacher conducted the lessons in the experimental and control groups. The teacher has a master's degree in science and has 12 years of professional experience.

In Table 1 below, a sample lesson plan suitable for periodic systems sub-acquisition of the Structure and Properties of Matter unit is presented. The activities implemented in the control group were prepared in line with the textbook proposed by the Ministry of National Education. The activities in the experimental group were prepared by the researchers according to the mobile learning approach. In addition, in the experimental group, there was a continuous interaction with software outside the classroom and e-contents related to the course were shared. Students asked questions with this software whenever they had questions and the teacher gave immediate feedback. A sample lesson plan regarding the experimental and control group course processing process is presented in Table 1.

\section{Data Analysis}

As a result of the experimental processes, the necessary assumptions were checked and analyzed. Since the study groups were fifteen students or less, it was decided to perform the Mann-Whitney $U$ and Wilcoxon tests among non-parametric tests. In addition, semi-structured interview forms with students were subjected to content analyzes by the researcher. Students were asked to evaluate the questions in the semi-structured interview form in writing.

\section{Validity and Reliability of the Study}

Necessary measures have been taken to increase the reliability and validity of the study. During the development of the academic achievement test, the measures regarding the quantitative part of the research were determined in detail and the necessary analyses were made. Descriptive statistics (mode, median, mean, standard deviation, etc.) were examined for the data obtained after the application and it was observed that the data were not distributed normally. In addition, the necessary assumptions for the Mann-Whitney $\mathrm{U}$ and Wilcoxon tests were checked.

In the qualitative part of the study, two experts were consulted for the items developed by the researcher. Data from interviews were recorded and analyzed through the MAXQDA Analytics Pro program. Students' opinions were also taken in writing. The opinions of the interviewed students were selected by random sampling method and these opinions were directly quoted. The descriptions and comments have been associated with the literature. For internal reliability, consistency between the opinions obtained from the students was examined. For external reliability, three academicians who are experts in their field have been examined to confirm the data.
Table 1: Experimental and control group course processing process

\begin{tabular}{|c|c|}
\hline Control Group & Experimental Group \\
\hline $\begin{array}{l}\text { "What is the periodic system } \\
\text { used for?" The question was } \\
\text { directed to the students. }\end{array}$ & $\begin{array}{l}\text { The "Let's Remember" event was } \\
\text { implemented to reveal students' prior } \\
\text { knowledge. The application related to } \\
\text { the "first } 18 \text { elements in the periodic } \\
\text { system" that they learned in the previous } \\
\text { year from mobile devices was opened } \\
\text { and students searched the names and } \\
\text { symbols of common elements }\end{array}$ \\
\hline $\begin{array}{l}\text { After the answers from the } \\
\text { students, the text "Periodic } \\
\text { system" in the textbook was } \\
\text { read to the students and their } \\
\text { ideas were taken }\end{array}$ & $\begin{array}{l}\text { "Periodic system" activity was carried } \\
\text { out with mobile applications. With the } \\
\text { application used, a sense of curiosity } \\
\text { has been raised in the students and they } \\
\text { have been given the opportunity to do } \\
\text { research }\end{array}$ \\
\hline $\begin{array}{l}\text { "What is the difference } \\
\text { between the group and the } \\
\text { period in the periodic table?" } \\
\text { was directed to the students }\end{array}$ & $\begin{array}{l}\text { With the simulation of "My Periodic } \\
\text { Table I Discovered" prepared in line } \\
\text { with the periodic system, students' prior } \\
\text { knowledge was activated }\end{array}$ \\
\hline $\begin{array}{l}\text { After the answers of the } \\
\text { students, the text of "Groups } \\
\text { and Periods in the Periodic } \\
\text { System" in the textbook was }\end{array}$ & $\begin{array}{l}\text { The students were asked to prepare } \\
\text { their own mind maps to gather their } \\
\text { knowledge. And they were provided to } \\
\text { share these mind maps with their friends }\end{array}$ \\
\hline
\end{tabular}

read to the students and their ideas were taken

"How has the periodic system changed in the process to date?" was directed to the students and asked to research The students' research results are open to discussion in the classroom

"How is the electron-layer relationship?" was directed to the students

After the answers from the students, the text of the

"Electron-Layer Relationship of the First 18 Elements in the Periodic System" in the textbook was read to the students and their ideas were taken

Students are provided to research natural and artificial elements in the world and present them in the classroom

"How do atoms become stable?" was directed to the students

Students were provided to do the "Let's Make an Element Model" activity
Students were asked to fill in the work practice called "periodic table from past to present"

Concept structuring with videos was supported

The students were provided to exchange ideas with the "Panel" they organized. The students discussed their ideas about the periodic system in a software environment. Thus, it was tried to gain the habits of students to do educational activities in mobile environments The element model was designed by means of a software and it was provided to share the results with each other

Students watched the video titled "Natural and Artificial Elements" and they were asked to examine the text in a virtual environment with the Socratic method of discussion

Under the guidance of the teacher, how the atom became stable was discussed in a virtual environment and the social development of the students was provided

Students were given the opportunity to test the "Element Model" experiment in a virtual environment and to conduct research in similar environments 


\begin{tabular}{|c|c|}
\hline \multicolumn{2}{|l|}{ Table 1: (Continued) } \\
\hline Control Group & Experimental Group \\
\hline $\begin{array}{l}\text { "Do You Know These?" } \\
\text { text was read and a sense of } \\
\text { curiosity was created in the } \\
\text { students }\end{array}$ & $\begin{array}{l}\text { Students were asked to design and share } \\
\text { concept cartoons through an application } \\
\text { in a virtual environment }\end{array}$ \\
\hline $\begin{array}{l}\text { By solving the questions } \\
\text { in "Activity Questions 1," } \\
\text { students were provided to } \\
\text { reinforce the subject }\end{array}$ & $\begin{array}{l}\text { To connect with daily life, an event was } \\
\text { held with the "Element and Nature" } \\
\text { virtual application }\end{array}$ \\
\hline $\begin{array}{l}\text { "What We Have Learned?" } \\
\text { section was examined by the } \\
\text { students and the subject was } \\
\text { summarized }\end{array}$ & $\begin{array}{l}\text { The students were provided with } \\
\text { solutions to the problem in the } \\
\text { "Properties of Elements" application in } \\
\text { order to expand what they learned }\end{array}$ \\
\hline $\begin{array}{l}\text { With the "Unit Evaluation } \\
1 \text { " test, students had the } \\
\text { opportunity to test what they } \\
\text { learned }\end{array}$ & $\begin{array}{l}\text { The students were provided to solve the } \\
\text { test consisting of descriptive branched } \\
\text { tree, structured grid, word association } \\
\text { test, concept map and concept cartoons } \\
\text { in mobile environment }\end{array}$ \\
\hline
\end{tabular}

\section{FINDINGS}

\section{First Sub-problem Results}

The first sub-problem of the study was applied to SPMAAT to look for the "What is the effect of mobile learning on the academic achievement of the eighth-grade students' matters and properties unit?" question. Since the data met the necessary assumptions, they were analyzed by Wilcoxon tests and the Mann-Whitney U-test. Descriptive statistics for the analyses are presented in Table 2 .

The Mann-Whitney U-test was used to compare the pre-test and post-test mean scores to determine whether there was a difference between the experimental and control group student scores before and after the application. Findings are presented in Table 3.

When Table 3 is examined, it can be observed that there was no significant difference between the pre-test mean ranks of the experimental group and the pre-test mean ranks of the control group $(\mathrm{U}=91.50, \rho>0.05)$.

The data obtained because of the Mann-Whitney U-test analysis to determine whether the post-test mean scores of the experimental group students and the control group students were different are presented in Table 4.

When Table 4 is examined, it can be observed that there was significant difference between the post-test mean ranks of the experimental group and the post-test mean ranks of the control group $(\mathrm{U}=0.00, \rho<0.05)$.

The data obtained from the Wilcoxon-test analysis to determine whether there was a difference between the achievement of the experimental group students before and after the application are presented in Table 5 .

When Table 5 is examined, it can be observed that there was significant difference between the pre-test mean ranks of the experimental group and the post-test mean ranks of the experimental group $(Z=-3.19, \rho<0.05]$. The effect

\begin{tabular}{llccc}
\hline \multicolumn{4}{l}{ Table 2: SPMAAT descriptive statistics } & \\
\hline Group & Test & N & Mean & Sd \\
\hline Experimental Group & Pre-Test & 13 & 5.15 & .38 \\
& Post-Test & 13 & 14.07 & .17 \\
Control Group & Pre-Test & 15 & 4.93 & .30 \\
& Post-Test & 15 & 8.80 & .41 \\
\hline
\end{tabular}

Table 3: The difference between the pre-test mean scores of the experimental group students and the control group students

\begin{tabular}{llccccc}
\hline Test & Group & N & $\begin{array}{c}\text { Mean } \\
\text { Ranks }\end{array}$ & $\begin{array}{c}\text { Sum of } \\
\text { Ranks }\end{array}$ & $\boldsymbol{U}$ & $\boldsymbol{\rho}$ \\
\hline Pre test & Experimental Group & 13 & 14.96 & 194.50 & 91.5 & .77 \\
& Control Group & 15 & 14.10 & 211.50 & & \\
\hline
\end{tabular}

Table 4: Differences between the post-test mean scores of the experimental group students and the control group students

\begin{tabular}{llccccc}
\hline Test & Group & $\mathbf{N}$ & $\begin{array}{c}\text { Mean } \\
\text { Ranks }\end{array}$ & $\begin{array}{c}\text { Sum of } \\
\text { Ranks }\end{array}$ & $\boldsymbol{U}$ & $\boldsymbol{\rho}$ \\
\hline Post Test & Experimental Group & 13 & 22.0 & 286.0 & .00 & .00 \\
& Control Group & 15 & 8.0 & 120.0 & & \\
\hline
\end{tabular}

Table 5: The difference between the experimental group students' achievement before and after the application

\begin{tabular}{lccccc}
\hline Test & $\mathbf{N}$ & Mean ranks & Sum of Ranks & $\mathbf{Z}$ & $\boldsymbol{\rho}$ \\
\hline Post-test/pre test & & & & & \\
Negative ranks & 0 & .00 & .00 & -3.19 & .00 \\
Positive ranks & 13 & 7.0 & 91.0 & & \\
\hline
\end{tabular}

size obtained from the experimental group was found to be $\eta 2=0.97$ and it was observed that it had a significant magnitude effect.

The data obtained from Wilcoxon test analysis to determine whether there was a difference between the achievement of the control group students before and after the application are presented in Table 6.

When Table 6 is examined, it can be observed that there was a significant difference between the pre-test mean ranks of the control group and the post-test mean ranks of the control group $(Z=-3.30, \rho<0.05)$. The effect size obtained from the control group was found to be $\eta 2=0.36$ and it was observed that it had a medium size effect.

Table 6: The difference between the control group students' achievement before and after the application

\begin{tabular}{lccccc}
\hline Test & N & Mean Ranks & Sum of Ranks & $\mathbf{Z}$ & $\boldsymbol{\rho}$ \\
\hline Post-test/pre-test & & & & & \\
Negative ranks & 0 & 0.00 & 0.00 & -3.30 & .00 \\
Positive ranks & 14 & 7.50 & 105.00 & & \\
\hline
\end{tabular}




\section{Second Sub-problem Results}

The second sub-problem of the study was applied to the semi-structured interview form to look for the "What are students' views on mobile learning?" question. As a result of the semi-structured interview with the experimental group students about mobile learning. In this respect, semi-structured questions about mobile learning were asked to the experimental group students.

The students mentioned that they enjoyed the mobile learning method very much that they felt very free and that they could research quickly thanks to the internet. They could search at any time. They also talked about using software to communicate with their teachers at any moment and reduce their anxiety about getting answers to their questions. One of the students commented "I found the answer by writing the questions asked by my teacher on the internet..." while another student stated:

It was fun to discuss with friends from the phone. Some of my friends objected to the question that the teacher asked and answered correctly. I found the correct answer from the source and took the photo, sent it to my friends...

These answers have shown that the practice did contribute to the social skills and communication skills of the students. It should also be noted that the student referred to research.

Students were also constantly interacting through software outside the boundaries of the school and their class time. It was observed that they tried to solve the problem by sharing their progress in the homework on the group interview page. Some students were observed to have no interaction outside the school. One of the students commented "I was so bored at home after school. But now we are constantly talking to my friends, sharing. I think this practice should always be..." while another student reported "My father helped me in the question that I could not solve. Now I am sharing in the group, surely someone answers. When my answer is wrong, my teacher immediately warns me." Another student did complain about the frequency of communication "some of my friends never quit, they keep sending messages, it gets very tiring..."

When asked about the points of view toward science and technology lesson, they explained that they now find the course more interesting and realized that science and technology were very interesting lessons. They noted that there were some positive opinions against the course. According to one student "my teacher shared very interesting pictures and videos. I loved it a lot. It was great to be able to talk about my lesson with my teacher..." While another student stated "in the lessons, the scientists who passed the name had strange lives. I knew their constant course was working. They were enjoying science and technology lessons. I'm starting to like it..."

The increase in the academic achievement of the students toward the course was statistically observed. They mentioned that they learned better in their own words, understood the concepts they did not know better, and that it was very useful to get feedback instantly. As indicated by one of the students "I feel like I'm taking private lessons. I thought my teacher was right next to me. I think I'm more successful..." This was similar to a peer who commented "My notes have risen. According to the first test I made two more accurate. I also knew a question, but I blurred it. I actually knew that question..."

When asked about the positive aspects of mobile-supported learning activities, students were more interested in the play and entertainment of the application. They talked about constantly playing online games and joking about some friends in lessons break. In particular, when asked about their views on the classroom, they talked about increased motivation for in-school and out-of-school study, two representative comments:

"The school has become very enjoyable. After school I interviewed my friends and teachers. If I do not have my homework, I have the question, the answer, and I learned..."

"It was too late after school and after school to get out of court. I missed the house, so I wanted to finish the lesson immediately and go home and play. Now I called my mother in the classroom. She told me to listen to the lesson well. I'm listening to my teacher carefully..."

When asked about the negative aspects of mobile-supported learning activities, some students stated that they did not have negative attitudes. They have always said that such a process should be done. Some students have been criticized in a wide variety of negative aspects. According to three students:

"I could not upload pictures and videos because it reduces internet pacification. But my friends did. I did not download their video. I'm sorry..."

"Some of my friends talked about the game, not about the course, I never liked it..."

"When researching on the phone, the phone is constantly entering other sites. They are very annoying..."

It has been observed that some students did not use the scientific process steps well. It has been determined that many students plagiarized without reference as noted by these two students "I do not understand some difficult concepts. There are things I learned, but I would like the teacher to tell some of the topics on the board..." and "I immediately copied and pasted the question my teacher asked. I can easily reach everything now..."

\section{DISCUSSION AND RECOMIMENDATIONS}

When the findings of the research were examined, there was no significant difference between the pre-test scores of the experimental and control groups [Table 3]. When the independent samples t-test results of the experimental group and the control group were examined, it was seen that the 
preliminary information of the substance was close to each other.

There was a significant difference between the post-test scores of the experimental and control groups [Table 4]. When the results of the independent samples t-test of the experimental group and the control group were examined, it was seen that the academic achievement of the experimental group students was higher in the structure and properties of the substance after the application.

When the pre-test and post-test scores of the experimental group students were examined, a significant difference was found in favor of the post-test [Table 5]. The findings show that the students who conducted their courses according to mobile learning were successful in academic terms. These results concur with those studies reporting that mobile supported learning increased the academic achievement of students (Elçiçek and Bahçeci, 2017; Hsu et al., 2008; Rau et al., 2008; Yıldırım, 2012). Oberer and Erkollar (2013) found that the use of mobile tools in education would increase the academic achievement positively. Tarman and Baytak (2011) explained that mobile tools enriched and facilitated educational environments. One of the reasons for increasing students' achievement is that mobile learning activities enable students to practice and facilitate the process through activities (Schelhowe and Zare, 2009).

In the control group, research and inquiry-based science teaching was conducted. There was a significant difference in favor of the post-test when the post-test scores of the control group were compared with the control group [Table 6]. The findings show that the control group students were also academically successful. The reason for this success was the effect of research and inquiry-based learning on students' conceptual comprehension levels (Sağlamer Yazgan, 2013), their effect on problem solving skills (Alkan Dilbaz, 2013), and their effect on cognitive strategy dimensions (Ulu, 2011). The research and interrogation approach were effective for the development of empathy skills in students (Greenstein, 2010), increasing the ability of critical thinking (Wu and Hsieh, 2006), developing a positive motivation (Tuan et al., 2005), and increasing academic success (Bağcaz, 2009; Duban, 2008; Suarez, 2011; Taşkoyan, 2008). As a matter of fact, techniques such as question-answer, discussion, and brainstorming in the control group were thought to support this situation. These conditions could be considered as the reason for the positive increase in the control group.

The academic achievement of the experimental group students was higher than the control group. The effect size obtained from the experimental group was found to be $\eta 2=0.97$ and it was observed that it had a significant magnitude effect. The effect size obtained from the control group was found to be $\eta 2=0.36$ and it was observed that it had a medium size effect. It was seen that the experimental group was more successful when the effect sizes occurring in both groups were compared.
As a result of the continuous and rapid progress of technology, many areas such as education were affected by this change. In today's world, almost everyone has smart phones. These mobile tools should be used in education to enrich learning environments (Sung et al., 2015). Thus, students would be more able to actively participate in the course and more productive learning could take place (Dikbaş, 2006).

Thanks to mobile tools, students would be able to do activities both individually and collaboratively. Indeed, with this research, students who had the opportunity of individual activities during the lesson emphasized that they interacted with their friends outside the lesson and that this situation had a positive effect on their socialization. In addition, the students would be able to determine the appropriate levels and prepare lesson plans according to the level of readiness. Improper structuring of the concept could be prevented by giving immediate feedback to the teacher who has become a guide (Rogers, 2011).

If the mobile tools can be used positively through the online feature, they can fit into the tremendous libraries (course materials, educational games and videos, etc.) and be put into service for the purpose of doing research. However, it was observed that the students could not use the scientific process steps as a result of the observations. Their only activity was to scan the browser by typing random expressions on the search button. Korkmaz (2014) noted students should be educated about internet technologies. Therefore, the students experienced problems in reaching the desired result. In the research, it was observed that the students could not make efficient research about the gains.

An impressive environment for communication skills can be created with the mobile tool. Students can learn what they do not know with social learning and discover the information they do not have. Corbeil and Valdes-Corbeil (2007) explained that mobile learning environments eliminate cultural and communication barriers. In the internet literacy report published by Council of Europe (URL3) (2009), teachers explained that using the SMS, "WhatsApp," group conversations as a means of learning, students could focus on their interest and this increased their motivation. As a result of the application, it was observed that students made progress in terms of scientific knowledge. But they had trouble making critical comments. When the comments were examined, each student had an individual correspondence, rather than commenting on the sharing of their friends, they focused on their own comments. Instead of supporting each other, they preferred to criticize more. Students need to improve about constructive criticism. Furthermore, Ertuğrul and Keskin (2012) stated that Turkish schools have missed effectively use of internet environments and students have communication problems. For this reason, it is recommended to prepare programs for students to acquire desired understanding for the language needed to effectively use the internet.

When the correspondences in the application were examined, language errors were observed to a great extent. While many 
of these errors were in the direction of abbreviating words, other errors arose because the technological tools were not used effectively. In fact, Yaman and Erdoğan (2007) stated that the words were frequently shortened in virtual environments and this had a negative effect on Turkish development. Great differences were observed between the ideas of students in daily life and the ideas they present in the mobile environment. The findings obtained from the interview form supported this situation. Konrath et al. (2011) explained that students' empathy skills decreased as new communication technologies developed. Tanhan and Alav (2015) explained that technology has negatively affected mirror neurons, which have an important role in empathy. Selkie et al. (2015) reported that students showed less respect for each other in virtual environments.

Some students shared the information they obtained from the internet without saving them. This has made it difficult to acquire metacognitive skills. Nevertheless, most of the students were academically higher. The reason for this was that mobile learning has been tailored to students' multiple intelligence areas (Madianou, 2014). Visual, verbal, and social aspects have been supported by students. Immediate intervention was made with the guidance of teachers and wrong learning was prevented.

There were some technical problems when mobile devices were online. Some students explained that the internet was slow, and this situation affected the process negatively. Overloading to the internet caused a slowdown. It was also thought that some viruses may adversely affect the system. According to Wagner (2005), the biggest obstacle to mobile learning was infrastructural problems. Sur (2011) stated that mobile devices and internet infrastructure require cost and this may negatively affect learning environments.

Students were generally satisfied with mobile-aided learning. They mentioned that the process was entertaining and educative. In fact, in similar studies, it has been observed that mobile supported learning facilitates educational environments (Garcia-Cabot et al., 2015; Fernandez-Lopez et al., 2013; Rogers, 2011). They explained that learning could occur in almost any environment. The nature of mobile learning is a learning environment that provides more freedom than the four wall boundaries of classrooms (Ally, 2009; Moura and Calvalho, 2012; Peng et al., 2009; Yang, 2013).

This research was limited to 28 students studying in the $8^{\text {th }}$ grade of a public secondary school. In addition, the research was limited to the Structure and Properties of the Substance unit with 6 weeks of application.

\section{CONCLUSION}

The results obtained in line with the problems of this study are as follows:

1 The academic achievement of $8^{\text {th }}$ grade secondary school students who received education according to mobile-assisted learning and program-oriented education showed a statistically significant increase. However, the academic achievement of the students who received education according to mobile-assisted learning increased statistically significantly more than those who received program-oriented education.

2 Students were generally satisfied with mobile-assisted learning. They mentioned that the process was entertaining and educational.

\section{REFERENCES}

Aksoy, H.H. (2003). An analysis of the use of technology and its effects in educational institutions. Education Science Society Journal, 1(4), 4-23.

Alkan Dilbaz, G. (2013). The Effect of Research-based Learning on Attitude, Academic Achievement, Problem Solving and Research Skills. (Master Dissertation, Mersin University, Turkey).

Ally, M. (2009). Mobile Learning: Transforming the Delivery of Education and Training. Athabasca, Canada: Athabasca University Press.

Atıc1, B. (2010). The effects of virtual learning environments based on social knowledge construction on student achievement and attitudes. Education and Science, 32(143), 91-103.

Bağcaz, E. (2009). The Effect of the Inquiry Teaching Method on Students' Academic Achievement and Attitude Towards Science and Technology Lesson. (Master Dissertation, Sakarya University, Turkey).

Balay, R. (2004). Globalization, information society and education. Ankara University Journal of Educational Sciences, 37(2), 61-82.

Bandura, A., \& Walters, R.H. (1977). Social Learning Theory. Vol. 1. United States: Prentice-Hall.

Bayar, M.F., Kurt, M., \& Haşıloğlu, A. (2018). Science and technology course in educational information network a review on videos. Universal Journal of Educational Research, 6(3), 413-420.

Berg, B.L. (2001). Qualitative Research Methods for the Social Sciences. $4^{\text {th }}$ ed. United States: Allyn \& Bacon.

Carvalho, A. (2012). Mobile Learning: Rentabilizar os dispositivos móveis dos alunos para aprender. In: Carvalho, A. A. (Ed.), Aprender na Era Digital: Jogos e mobile learning. Santo Tirso: DeFacto Editora, pp.149-163.

Caudill, J.G. (2007). The growth of m-learning and the growth of mobile computing: Parallel developments. The International Review of Research in Open and Distributed Learning, 8(2), 1-13.

Centre of Language Education. (2018). Basic Principles of Mobile Learning. Available from: https://www.teachthought.com/learning/12-principlesof-mobile-learning/.

Chinnery, G.M. (2006). Emerging technologies. Going to the mall: Mobile assisted language learning. Language Learning and Technology, 10(1), 9-16.

Coakes, S.J., \& Steed, L.G. (1997). SPSS, Analysis Without Anguish. United States: John Wiley and Sons Publishing.

Cohen, J. (1988). Statistical Power Analysis for the Behavioral Sciences. $2^{\text {nd }}$ ed. United States: Lawrence Erlbaum Associates.

Corbeil, J.R., \& Valdes-Corbeil, M.E. (2007). Are you ready for mobile learning? Educause Quarterly, 30(2), 51-58.

Creswell, J.W. (2014). A Concise Introduction to Mixed Methods Research. United States: Sage Publications.

Creswell, J.W., \& Creswell, J.D. (2017). Research Design: Qualitative, Quantitative, and Mixed Method Approaches. United States: Sage publications.

Dikbaş, E. (2006). Examination of Pre-service Teachers'Attitudes Towards E-learning. (Master Dissertation, Dokuz Eylül University, Turkey).

Duban, N. (2008). Teaching the Primary School Science and Technology Lesson According to the Inquiry-based Learning Approach: An Action Research. (Doctoral Dissertation, Anadolu University, Turkey).

Ekici, S., \& Y1lmaz, B. (2013). An evaluation on FATİH project. Turkish Librarianship, 27(2), 317-339.

Elçiçek, M., \& Bahçeci, F. (2017). Examination of the effects of mobile learning management system on learners' academic success and attitudes. Kastamonu Education Journal, 25(5), 1695-1714. 
Ertaş, H., Şen, A.İ., \& Parmaksızoğlu, A. (2011). The effect of out-of-school scientific activities on the level of $9^{\text {th }}$ grade students associating energy with daily life. Necatibey Faculty of Education Electronic Journal of Science and Mathematics Education, 5(2), 178-198.

Ertuğrul, İ., \& Keskin, N. (2012). The role of the Internet in the use of Turkish and in the change of society-individual structure. Journal of Internet Applications and Management, 3(2), 79-88.

Fernandez-Lopez, A., Rodriguez-Fortiz, M.J., Rodriguez-Almendros, M.L., \& Martinez-Segura, M.J. (2013). Mobile learning technology based on IOS devices to support students with special education needs. Computers and Education, 61, 77-90.

Garcia-Cabot, A., de-Marcos, L., \& Garcia-Lopez, E. (2015). An empirical study on m-learning adaptation: Learning performance and learning contexts. Computer and Education, 82, 450-459.

Greenstein, S.B. (2010). Empathy in Inquiry: Supporting Middle School Science Students in Developing Empathy Through Group Reflections During Guided Inquiry. (Master Thesis, University of California, San Diego, CA)

Gürkan, F. (2017). Examining the Attitudes of Students Studying in Open and Distance Education Towards Mobile Learning. (Master Dissertation, Marmara University, Turkey).

Hsu, H.Y., Wang, S.K., \& Comac, L. (2008). Using audio blogs to assist English-language learning: An investigation into student perception. Computer Assisted Language Learning, 21(2), 181-198.

İșman, A. (2008). Distance Learning. Turkey: Pegem Akademi.

Kamac1, E., \& Durukan, E. (2012). A qualitative study on research assistants' views about using tablet pc in education (Trabzon sample). International Journal of Turkish Literature Culture Education, 1(3), 203-215.

Kapıdere, M., \& Çetinkaya, H.N. (2017). Evaluation of education information network mobile application. International Journal of Active Learning, 2(2), 1-14.

Keskin, N.Ö., \& Kılınç, A.G.H. (2015). Comparison of development platforms and sample applications for mobile learning applications. Journal of Open Education Applications and Research, 1(3), 68-90.

Kılıç, M. (2015). The Effect of Mobile Learning Based Android Applications on Students' Academic Achievement, Permanent Learning and Motivation in Chemistry Lesson Atomic and Periodic System Unit. (Master Dissertation, Kahramanmaraş Sütçü İmam University, Turkey).

Konrath, S.H., O'Brien E.H., \& Hsing, C. (2011). Changes in dispositional empathy in American college students over time: A meta-analysis. Personality and Social Psychology Review, 15: 180-198.

Korkmaz, M. (2014). New Approach in Education: E-learning. Tamil Nadu: AR\&GE Academy.

Köseoğlu, F., \& Tümay, H. (2013). Constructivist Paradigm in Science Education. Ankara: Pegem Academy.

Küle, G. (2012). Determining the Students Who Educated Marketing Management Lesson Mobile Learning Perception. (Master Dissertation, Bahçeşehir University, Turkey).

Lan, Y.F., \& Hsieh, C.L. (2009). The design of a question solving mechanism to encourage students to participate in learning activities through handheld mobile devices. In: Virtual Environments, Human-Computer Interfaces and Measurements Systems. United States: VECIMS'09. pp. 261-265.

Madianou, M. (2014). Smartphones as polymedia. Journal of Computer Mediated Communication, 19(3), 667-680.

Mahat, J., Ayub, A.F.M., \& Luan, S. (2012). An assessment of students' mobile self-efficacy, readiness and personal innovativeness towards mobile learning in higher education in Malaysia. Procedia Social and Behavioral Sciences, 64, 284-290.

Mcconatha, D., Praul, M., \& Lynch, M.J. (2008). Mobile learning in higher education: An empirical assessment of a new educational tool. Turkish Online Journal of Educational Technology-TOJET, 7(3), 15-21.

MoNE. (2015). FATIH Project in Education Web Page. Available from: http://fatihprojesi.meb.gov.tr/.

Morse, J.M. (2016). Mixed Method Design: Principles and Procedures. England, UK: Routledge.

Motiwalla, L.F. (2007). Mobile learning: A framework and evaluation. Computers and Education, 49(3), 581-596.

Moura, A., \& Carvalho, A. (2012). The ARCS model to motivate language learning through SMS and podcasts. Journal of Communications Research, 4(4), 385.

Oberer, B., \& Erkollar, A. (2013). Mobile learning in higher education: A marketing course design project in Austria. Procedia Social and Behavioral Sciences, 93, 2125-2129.

Öztürk, M.F., \& Talas, M. (2015). Interaction of social media and education. Journal of World of Turks, 7(1), 101-120.

Peng, H., Su, Y.J., Chou, C., \& Tsai, C.C. (2009). Ubiquitous knowledge construction: Mobile learning re-defined and a conceptual framework. Innovations in Education and Teaching International, 46(2), 171-183.

Rau, P.L.P., Gao, Q., \& Wu, L.M. (2008). Using mobile communication technology in high school education: Motivation, pressure, and learning performance. Computers and Education, 50(1), 1-22.

Rogers, K.D. (2011). Mobile Learning Devices. Tamil Nadu: Solution Tree Press.

Rosenberg, M.J. (2001). E-Learning: Strategies for Delivering Knowledge in the Digital Age. Vol. 3. United States: McGraw-Hill.

Ruchter, M., Klar, B., \& Geiger, W. (2010). Comparing the effects of mobile computers and traditional approaches in environmental education. Computers and Education, 54(4), 1054-1067.

Sağlamer Yazgan, B. (2013). The Effect of Inquiry Based Outdoor Laboratory Activities on Student's Inquiry-query Abilities and their Attitudes Towards the Environment. (Doctorate Dissertation, Marmara University, Turkey).

Schelhowe, H., \& Zare, S. (2009). Intelligent mobile interaction: A learning system for mentally disabled people (IMLIS). In: Universal Access in Human-computer Interaction. International Conference on Universal Access in Human-Computer Interaction. Berlin, Germany: Springer. pp. $412-421$.

Selkie, E.M., Fales, J.L., \& Moreno, M.A. (2015). Cyberbullying prevalence among us middle and high school-aged adolescents: A systematic review and quality assessment. Journal of Adolescent Health, 58, 125-133.

Semerci, Ç., Yavuzalp, N., \& Bektaş, C. (2004). Conceptual relationships from e-learning to m-learning. In: $4^{\text {th }}$ International Educational Technology Conference (IETC2004). Turkey, Sakarya: Sakarya University.

Şenel, M. (2016). Analysis of elt students' perceptions as to mobile phones through metaphors. Kastamonu Education Journal, 24(4), 1749-1764.

Sharples, M., Taylor, J., \& Vavoula, G. (2010). A theory of learning for the mobile age. Medienbildung in Neuen Kulturräumen, 22, 87-99.

Suarez, M.L. (2011). The Relationship Between Inquiry-based Science Instruction and Student Achievement. (Doctoral Dissertation, The University of Southern Mississippi, Mississippi, USA).

Sung, Y.T., Chang, K.E., \& Yang, J.M. (2015). How effective are mobile devices for language learning? A meta-analysis. Educational Research Review, 16, 68-84.

Sur, E. (2011). Example and Comparison of Web-based and Mobile Instruction Strategies in Learning Computer Units (A Practice of Sinop Universty). (Master Dissertation, Gazi University, Turkey).

Tabachnick, B.G., \& Fidell, L.S. (2000). Using Multivariate Statistics. $4^{\text {th }}$ ed. United States: Allyn and Bacon.

Tanhan, F., \& Alav, Ö. (2015). The effect of cyber personalities on personality: Proteus effect. Online Journal of Technology Addiction and Cyberbullying, 2, 1-19.

Tanriverdi, M. (2011). Development of a Mobile Learning Application to Support E-learning and Analyze Its Effects. (Master Dissertation, Gazi University, Turkey).

Tarman, B., \& Baytak, A. (2011). The New Role of Technology in Education: Social Studies Teacher Candidates' Perceptions. Gaziantep University Journal of Social Sciences, 10(2), 891-908.

Taşkoyan, N.S. (2008). The Effect of Inquiry Learning Strategies on Students? Skills of Inquiry Learning, Academic Success and Attitudes. (Master Dissertation, İzmir Dokuz Eylül University, Turkey).

Traxler, J. (2007). Defining, discussing and evaluating mobile learning. International Review of Research in Open and Distance Learning, 8(2), $1-12$.

Trifonova, A., \& Ronchetti, M. (2004). A general architecture to support mobility in learning. In: IEEE International Conference on Advanced Learning Technologies Proceedings. United States: IEEE. pp. 26-30. 
Tuan, H.L., Chin, C.C., Tsai, C.C., \& Cheng, S.F. (2005). Investigating the effectiveness of inquiry instruction on the motivation of different learning styles students. International Journal of Science and Mathematics Education, 3(4), 541-566.

Turgut, M.F. (1992). Measurement and Evaluation Methods in Education. Turkey: Saydam Press.

Türnüklü, A. (2001). Using different research techniques for the same question in educational science. Education and Science, 26(120), 8-13.

Ulu, C. (2011). The Effect of Using Inquiry Based Approach Known as the Science Writing Heuristic on Concept Learning, Science Process and Metacognition Skills in Science Teaching. (Doctorate Dissertation, Marmara University, Turkey).

URL3. (2017). Internet Literacy Handbook. Available from: https://edoc. coe.int/en/internet/7515-internet-literacy-handbook.html.

Wagner, E.D. (2005). Enabling mobile learning. Educause Review, 40(3), 40-53.

Wu, H., \& Hsieh, C. (2006). Developing sixth graders' inquiry skills to construct explanations in inquiry-based learning environments.
International Journal of Science Education, 28(11), 1289-1313.

Yaman, H., \& Erdoğan, Y. (2007). The influence of internet on the Turkish language: A qualitative study. Journal of Language and Linguistic Studies, 3(2), 237-249.

Yang, J. (2013). Mobile assisted language learning: Review of the recent applications of emerging mobile technologies. English Language Teaching, 6(7), 19-25.

Yang, S.H. (2012). Exploring college students' attitudes and self-efficacy of mobile learning. Turkish Online Journal of Educational Technology, $11(4), 148-154$.

Yıldırım, A., \& Şimşek, H. (2011). Qualitative Research Methods in the Social Sciences. Turkish: Seçkin Press.

Yıldırım, N. (2012). Mobile Learning in Foreign Language Education with Educational Games. (Doctorate Dissertation, Firat University, Turkey).

Yokuş, G. (2016). Education Faculty Undergraduate Students' Perceptions of Mobile Learning: A Review and a Mobile Application Development Study Towards Educational Sciences: Mobile Academy. (Master Dissertation, Mersin University, Turkey). 